\title{
IAMJ
}

INTERNATIONAL

AYURVEDIC

MEDICAL JOURNAL

\section{A STUDY OF ROLE OF AAHARIYA DRAVYA ATASI (LINUM USITATISSIMUM LINN.) ON HYPERCHOLESTEROLEMIA}

\section{Shrilaxmi R. Chintaliah ${ }^{1}, \underline{\text { Rajkumar Bobade }}^{2}$}

${ }^{1}$ Assistant Professor, Swasthavritta and Yoga department, BAMC, Amroha, Uttar Pradesh, India

${ }^{2}$ Vice Principal \& HOD Swasthavritta and Yoga Department College of Ayurved and Reasearch Centre, Akurdi, Maharashtra, India

\section{Corresponding Author: c.shrilaxmi@gmail.com}

\section{https://doi.org/10.46607/iamj04p5062021}

(Published online: September 2021)

Open Access

(C) International Ayurvedic Medical Journal, India 2021

Article Received: 25/08/2021 - Peer Reviewed: 12/09/2021 - Accepted for Publication: 15/09/2021

Check for updates

\section{ABSTRACT}

The presence of an abnormally large amount of cholesterol in the blood is called Hypercholesterolemia which has been developed due to a sedentary lifestyle. The liver is the main organ for producing cholesterol in the body. Staulya (Obesity) which is included in Ashtau-Nindhita-Purusha (8 physical deformities) by Acharya Charaka (Ch. Su.21) is the disease caused due to vitiated Meda. As cholesterol is formed by fatty tissue i.e. Meda explained in Ayurvedic literature. So, both the entities can be correlated as they both have the same composition i.e. fatty tissue. The present study aimed to find out the role of Ahariya Dravya (dietary substance) Atasi (flax seeds) administered twice a day for 3 months duration on patients of Hypercholesterolemia and some factors of Staulya. After conducting the study, the observations and results were obtained.

Keywords: Hypercholesterolemia, Staulya, obesity, Atasi, flax seeds

\section{INTRODUCTION}

Health is the primary imperative feature, deprived of which an individual cannot live life opportunely and serenely. Owing to which disease like Staulya (Obe- sity) and Hypercholesterolemia has developed. Hypercholesterolemia has been unveiled to have a prevalence of $10 \%$ in Maharashtra. The liver is the fore- 
most organ for producing cholesterol in the body. There is a modification in liver function which affects the production of cholesterol which leads to the deposition of saturated fats in the body. In arrears to this, obesity surges and leads to a surge in total serum cholesterol. By evaluation of Samhitas (classical literature) about Aahar (Diet), it is perceived that Atasi has Kaphaghna (vitiate Kapha Dosha) properties. Kapha and Meda are in Aashrya-Aashrayi-Sambandh (inseparable relation like of abode and resident) with each other, and they mutually have equivalent Panchabhauthic $($ Panch $=$ five and Bhuta $=$ entity) Sangathan (combination). Atasi can be used in Staul$y a$ as it is Katu (pungent) Vipaki (taste at the end of digestion), Ushna (hot) Virya (potency) and Ruksha (dryness) Guna(quality) which acts as Kaphaghna and may similarly act on Medodhatu (fatty tissue) as Medohar (vitiates fat). Staulya has been explained Charak Samhita. Some of the Hetus(causative factors) of Staulya are Vyayam Abhav (Lack of exercise), Divaswapa (sleep during day time), Shleshma Aahara Sevan (fatty diet intake) which contains Madhur Ras (sweet taste) and Snigdha Guna Aahar (Oily diet) etc. In the Samprapti (etiogenesis) of Staulya, Kapha is main Dosha (humour) and Meda (fat) is the main Dushya in which Agnimandya (dyspepsia) leads to specific Dhatu (tissue)- Agnimandya which disturbs the proper development of $\mathrm{Me}$ dadhatu, so the quantity of Apachitmeda (undigested fat) i.e. Kleda (waste) increases. Conferring to modern science, Atasi (Linum usitatissimum Linn.) comprehends omega 3 fatty acids. Omega 3 fatty acids are effective to diminish cholesterol predominantly to the diminution of low-density lipoproteins (LDL) and total cholesterol which are deliberated to be not virtuous for health. Conferring to Ayurveda, Meda obligates Snigdha and Ghana (solid) properties analogous to lipids which are oily and heavy. Hence Meda and lipids can be associated. So, conferring to Ayurveda there is Medo Dushti (vitiation) in Staulya and according to modern science, there is amplified levels of lipids leading to Hypercholestrolemia.
Aim and Objectives: To study the role of Atasi ( $\mathrm{Li}$ num usitatissimum Linn.) on Hypercholesterolemia and symptoms of Staulya

Materials and Methods: An open, randomized clinical study was accomplished

Selection of Patients: Patients are observed in Swasthavrita department OPD of College of Ayurveda and Research Centre, Akurdi. A pre-diagnosed patient with Serum cholesterol levels of more than $200 \mathrm{mg} / \mathrm{dl}$ and less than $300 \mathrm{mg} / \mathrm{dl}$ was reserved.

Drug Description: Atasi is Madhura (sweet), Tikta (bitter), Snigdha Gunatmka (having properties) and Katu Vipaki. Guru (heavy), Ushna in nature. It is Druk (Skin), Shukra (sperm) Vatgni (vitiates Vata Dosha) and Kapha Pitta Vinashini (decreases Kapha and Pitta Dosha). Atasi is Kaphgna, Vatghna as it has Snigdha, Ushna Gunas and Tikta and Madhur Ras. Kapha and Meda are in Aashrya Aashrayi Sambandh with each other and they both have the same Pancha Bhauthic Sangathan. Atasi can be used in Staulya as it is Katu Vipaki, Ushna Virya and Ruksha Guna which acts as Kaphaghna.

Dose and Duration of Drugs: The dose was 10 $\mathrm{gm} /$ day $(5 \mathrm{gm}$ in morning and evening correspondingly). Anupam (adjuvants) was Koshna Jal (lukewarm water). Bhaishajyakaal (time of drug administration) was Pragbhakt (before breakfast and dinner). The period of the clinical study was 3 Months. Follow up was after every 1 month

Withdrawal Criteria: The investigator textures that the etiquette has been desecrated or the patient has become incorporative. Patients inattentive for continuous 2 follow-ups were reflected as plummeted out from this trial. Pitta pradhan Prakriti (Pita constitution) persons and with any foremost illness were omitted. So, 47 patients are enrolled but 7 were dropped.

\section{Results}

Levels of cholesterol and assessment of symptoms of Staulya are obtained after the completion of the clinical trial. The outcome after the clinical trial showed significant changes in levels of cholesterol and symptoms of Staulya. 
Serum cholesterol levels were checked before and after the treatment that is on the 0th day and the 90th day.

The decrease in levels of cholesterol in males is $0.31 \%$ and in females is $1.50 \%$. So, there is a significant change in cholesterol in females than in males. The obtained value of $p$ is 0.007 which suggests that there is a significant reduction in levels of cholesterol after 90 days. Out of 40 patients, 13 shows negative rankings. $32.5 \%$ of patients show a reduction in the level of Gatradaurgandhya. The value of $\mathrm{p}$ is 0.00 which is less than 0.05 . So, treatment is effective on Gatradaurgandhya because Sweda is Mala of Meda. So due to Kaphaghna property of Atasi Churna the Gatradaurgandhya is reduced. Swedadhikya Out of 40 patients 17 shows negative rankings. $42.5 \%$ of patients show a reduction in level of Swedadhikya. The value of $\mathrm{p}$ is 0.00 which is less than 0.05 . So, treatment is effective on Swedadhikya because Sweda is Mala of Meda. So, due to Kaphaghna property of Atasi Churna, the Swedadhikya is reduced. The value of $\mathrm{p}$ is less than 0.05 . Out of 40 patients, 25 shows negative rankings. $62.5 \%$ of patients show a reduction in the level of Atikshuda based on the amount of food. The value of $\mathrm{p}$ is less than 0.05 . So, treatment is effective on Atikshuda on basis of the amount of food. Based on Aharkal. Out of 40 patients, 23 shows negative rankings. $57.5 \%$ of patients show a reduction in the level of Atikshuda based on Aharkal. The value of $\mathrm{p}$ is 0.00 which is less than 0.05 . So, treatment is effective on Atikshuda based on Aharkal. It is because may be due to the delay Paripaka (end product) of Aahar by removing Aavaran (coating) of vata on Meda. Atipipasa. Out of 40 patients, 20 shows negative rankings. $50 \%$ of patients show a reduction in the level of Atipipasa. The value of $\mathrm{p}$ is 0.00 which is less than 0.05 . So, treatment is effective on Atipipasa because may be due to the delay Paripaka of Aahar by removing Aavaran of vata on Meda.

\section{DISCUSSION}

$25 \%$ of patients were found in the 20-40 years age group while $75 \%$ patients were found in the 40-60 years age group in which 60-year patients are also included. Maximum patients belong to the 40-60 age group. It may be because of unhealthy dietary regimens and more energy consumption and less energy expenditure. Lack of exercise leads to less energy expenditure. Maximum patients were female i.e. $60 \%$. Fat stores may be below 30 per cent and increase gradually to more than 35 per cent in older women whereas in men it increases up to 25 per cent only (Harrison's Principle of Modern Medicine). The prevalence of obesity is higher among women than among men. (Oxford's textbook of Medicine). It may be because of menopause, postoperative condition, predominant feminine factors, which makes females obese. Maximum patients are housewives followed by servicemen. The percentage of housewives was 37.5 and servicemen was 35 . It may be because of lack of exercise, unhealthy dietary habits etc. There is more accumulation of fats in women than men and as age increases this accumulation increases. So, there is more energy consumption and more energy expenditure which leads to Staulya and hypercholesterolemia. Diet pattern is divided into two i.e. vegetarian and mixed diet i.e. veg as well as non-veg. The patients consuming only vegetarian food are $57.5 \%$ and mixed diet is $42.5 \%$. Among which decrease in cholesterol in mixed diet patients are $0.75 \%$ and in vegetarian are $0.67 \%$. So, there is more decrease in levels of cholesterol is seen in the patients of a mixed diet. It may be because in a mixed diet there is a decrease in the frequency of non-veg consumption than before e.g. eating twice a week is decreased to once a week. So, there is more decrease in a mixed diet consuming patient. 
Table 1:

\begin{tabular}{|l|l|l|l|l|}
\hline Sr.No. & Parameter & $\begin{array}{l}\text { Mean score be- } \\
\text { fore treatment }\end{array}$ & Mean score after treatment & $\begin{array}{l}\text { Reduction in } \\
\text { parameter }\end{array}$ \\
\hline 1. & Total Cholesterol & 229.46 & 226 & 3.46 \\
& Male & 218.75 & 218.06 & 0.69 \\
& Female & 229.46 & 226.00 & 3.46 \\
\hline 2. & Gatradaurgandya (foul smell) & 1.05 & 0.75 & 0.3 \\
\hline 3. & Swedadikya (excessive sweating) & 1.37 & 0.95 & 0.42 \\
\hline 4. & Atikshudha (Increase in appetite) & 1.7 & 1.125 & 0.575 \\
& *On the basis of the amount of food & 2.82 & 1.62 & 1.2 \\
\hline 5. & *On the basis of Aharkal (frequency of intake) & 1.752 & 1.175 & 0.577 \\
\hline
\end{tabular}

\begin{tabular}{|l|l|l|l|}
\hline Sr.no. & \multicolumn{1}{|c|}{ Parameter } & \multicolumn{1}{|c|}{ Percentage } & Value of p \\
\hline 1. & $\begin{array}{l}\text { Total Cholesterol } \\
\bullet \quad \text { Male } \\
\bullet \quad \text { female }\end{array}$ & 0.31 & 0.007 \\
\hline 2. & Gatradaurgandya & 1.5 & 0.00 \\
\hline 3. & Swedadikya & $32.5 \%$ & 0.00 \\
\hline 4. & $\begin{array}{l}\text { Atikshudha } \\
\text { * Based on the amount of food } \\
\text { *On the basis of Aharkal }\end{array}$ & $42.5 \%$ & 0.00 \\
\hline 5. & Atipipasa & $62.5 \%$ & 0.00 \\
\hline
\end{tabular}

\section{CONCLUSION}

Atasi possesses the Kaphagna properties which help to reduce cholesterol and factors like Gatradaurgandya, Swedadhikya, Atikshudha, Atipipasa. So Atasi $10 \mathrm{gm} /$ day BD is effective in reduction of serum cholesterol and Gatradaurgandya, Swedadhikya, Atikshudha, Atipipasa after treatment.

\section{REFERENCES}

1. Indian medicinal plants volume -1, Kirtikar. K.R. and Basu, Dehradun, B.D. International book distributors, Edition -2008, Pg no.410

2. Nutritive value of Indian foods by, National institute of nutrition, C. Gopalan, B.V. Rama Sastri and S.C. Balasubramanian, Revised and updated by B.S. Narasinga Rao, Y.G. Deosthale and K.C. Pant reprint2004, 2007 Pg no. 210

3. The Ayurvedic Pharmacopoeia of India, part-1 \& volume -1, Government of India, Ministry of health and family welfare, department of Indian system of medicine and homoeopathy, new Delhi, First Edition, pg no. 19.

4. Bhavprakash nighantu part 1, Bramhashankar Mishra and Ruplalaji Vaishya, Chaukambha Sanskrit Bhavan, Varanasi, edition -11, dhanyadi Varga pg no 652-653

5. Sushrut Samhita-Shri dalhana aacharya virichitya nibhansangraha vyakya, Kaviraj Ambikadutt Shastri,
Varansi, Chaukhamba Sanskrit Snansthan, Reprint 2005.

6. Journal of Nutrition \& Food Sciences, Flax Seed: A Potential Medicinal Food- Charu Katare*, Sonali Saxena, Supriya Agrawal, GBKS Prasad and P.S. Bisen. Published January 23, 2012

7. Journal of nutrition and food sciences, Chemical Composition and Health Benefits of Flaxseed-by. Bernacchia R*, Preti R and Vinci G Austin Published: October 17, 2014.

8. Charak Samhita, Dr. Bramhanand Tripathi, Varanasi, Chaukamba Surbharati Prakashan, Reprint-2011

9. Kaiyyadeva Nighantu, Aacharya Priyavrat Sharma and Dr.Guruprasad Sharma ,Varanasi,Chaukambha orientaliyya ,Reprint edition 2009, pg no.207

10. Dhanvantari Nighantuh, Prof. Priya Vrat Sharma and Dr. Guru Prasad Sharma, Varanasi, Chaukhambha Orientalia, Reprint 2008

11. Raj Nighantu, Dr Indradev Tripahi and Aacharya Vishvanath Dwivedi, Varanasi, Krishnadas Academy, Edition- $2^{\text {nd }}$

\section{Source of Support: Nil \\ Conflict of Interest: None Declared}

How to cite this URL: C. Shrilaxmi R. Chintaliah \& Rajkumar Bobade: A Study Of Role Of Aahariya Dravya Atasi (Linum Usitatissimum Linn.) On Hypercholesterolemia. International Ayurvedic Medical Journal \{online\} 2021 \{cited September 2021\} Available from: http://www.iamj.in/posts/images/upload/3082_3085.pdf 